\title{
Emerging Leadership at Operational Level: The Convergence of Self-and Social Construction of Leadership
}

\author{
Kumudinei Dissanayake
}

\begin{abstract}
Operational level workers constitute an active and energetic workforce from which leaders emerge in organizations. Existing theories support the view that leadership is constructed by self and others. However, the process through which leaders emerge at operational level exists as an unattended agenda in leadership research. Thus, the purpose of this study is to examine and theorize how leaders emerge in a convergent process of self and social construction of leadership among operational level workers. This study is based on a comprehensive literature review followed by a case study. With the support of theories on impression construction, leadership outcomes, self-fulfilling prophecy, implicit leadership, and leader prototypes, the study identifies the emerged leadership at operational level as a convergent process of self- and social-construction at the workplace. Deploying a case from a labor-intensive industry for empirical support, the study develops eight propositions for this theorization. It finds that leadership in a large group of operational level workers emerges in a process consisting of: impressive engagement and symbolized positive performance of emerging leaders, and follower narrations and collective embracing of emerged leadership by peer followers. This theorization offers a cluster of implications for human resource managers, leader trainers, organizational line managers, and theorists while providing insights into the processes of emerging leadership at operational level. It recognizes the social processes enacted among young workers who belong to new generations, and emphasizes the significance of theorizing leadership construction processes of emerging leaders, while identifying their implications for organizations in managing new generations.
\end{abstract}

Keywords: emerged leadership, follower narrations, impressive engagement, operational level workers, self-construction, social construction, symbolic performance.

Kumudinei Dissanayake, $\boldsymbol{P h D}$ is a Senior Lecturer of the Department of Management \& Organization Studies, Faculty of Management \& Finance, University of Colombo. E-mail: k_dis@hotmail.com. 
Emerging Leadership at Operational Level: The Convergence of Self-and Social Construction of Leadership

\section{Introduction}

Researchers have accorded attention to leadership processes (Galvin, Balkundi \& Waldman 2010, Hannah, Walumbwa \& Fry 2011, Kark \& van Dijk 2007) with the acknowledgement that it is a collaborative construction of both leaders and followers (DeRue \& Ashford 2010). Further, these processes are seen as hierarchical, collective (Carson, Tesluk \& Marrone 2007), mutually influencial (Uhl-Bien, Marion \& McKelvey 2007), social (DeRue \& Ashford 2010), or integrative (Küpers 2007) processes. Apparently, most of the leadership studies draw heavily on such processes at organizational leader-follower interface at corporate, middle, or lower management level, leaving a void in the knowledge of how leadership emerges in a group of co-workers at operational level.

When a massive number of workers in groups or teams are at work, a few individuals who are embraced by other co-workers emerge as leaders. Traits, (House \& Aditya 1997, Stogdill 1974), charisma (Conger \& Kanungo 1998), style and behaviour (Kerr, Schereisheim, Murphy \& Stogdill 1974, Judge, Colbert \& Illies 2004), nature of relationship (Gerstner \& Day 1997), and particular context (Fiedler 1967, House 1971) have been used to explain the grounds for such leader emergence. However, these appear to be partial explanations which are leadercentric, thus ignoring the role of followers (Carsten, Uhl-Bien, West, Patera \& McGregor 2010, Dasborough, Ashkanasy, Tee \& Tse 2009) that gives birth to leaders. Instead, recent developments in leadership research support the claim that leadership is a co-construction by both leaders and followers (Field 2007, Meindl 1995, DeRue \& Ashford 2010).

Despite recent research directions drawn on leadership construction at group level (e.g., De Rue \& Ashford 2010), leadership research lacks investigations into the processes in which leaders emerge through the constructions among co-workers at the operational level. Operational level workers are at the non-managerial level or operating core (Mintzberg 1979) in a typical organization. Particularly, organizations in labor-intensive industries claim a large proportion of operational level workers skilled or unskilled. For instance, nearly $90 \%$ of the workforce in the garment and textile industry is composed of operational level workers (who are termed 'associates'). They are commonly characterized as young, skill-seeking, opportunity-finding, and shifting from job-to-job until they anchor in satisfying work or work place. Thus, they belong to a workforce, which would be retained and motivated in the existing workplace by tapping their expectations, and further developed and promoted to undertake managerial and leadership obligations in future endeavors. Most of them are at the exploration stage (attempting to identify work that creates interest) or trying to reach the establishment stage (finding their place in the organization and strengthening 


\section{NSBM Journal of Management}

Vol. 2, No. 1, January - June, 2016

their contributions) in their career (Super 1957). They add value to organizations through their 'young-blood' (energy and creativity) while being a flexible and dynamic workforce for undertaking heavy work for long hours or on a shift basis. Moreover, they are growthoriented and looking for self-development. Thus, it is at the entry level that organizations identify future leaders or managers through their work-related attitudes such as commitment, loyalty, and involvement, etc. (Luthans 2008).

With the support of the existing literature, in the present research, I base my conceptualization on the premise that leadership that emerges at operational level in work organizations is a construction of the prospective (emerging) leaders and their co-workers. In my theorization self-construction of leadership by emerging leaders and social construction of leadership by co-workers or followers converge.

The efforts of self-construction of image are well explained in the theory of impression management (Rosenfeld, Giacalone \& Riordan 1995), while follower perceptions of leaders are theorized in implicit leadership theories and leader proto-typicality. These two major streams of knowledge may help us understand how leader's 'self' and follower perceptions together help leaders to emerge from among operational level workers.

Accordingly, my goal here is to draw from theories on image construction, leadership outcomes, self-fulfilling prophecy, and implicit leadership and leader prototypes to develop a conceptual framework in order to advance future studies on the process of self- and social construction of emerged leadership of operational level workers. I argue that leadership in a large group of operational level workers emerges in a process of: (1) impressive engagement, (2) symbolized positive performance, (3) follower narrations, and (4) collective embracing of emerged leadership.

Most of the operational level workers in contemporary organizations belong to the new generation of workers (Joshi, Dencker \& Franz 2011, Mattis, Gerkovich, Gonzales \& Johnsen 2004). In line with the new generations stepping into workplaces and proceeding to managerial positions, research interest has grown to examine leadership outcomes in such contexts (e.g. Carucci \& Epperson 2011, Penny \& Neilson 2010, Mhatre \& Conger 2011). Developing insights into the processes of emerging leadership at operational level, I bring into focus the social processes enacted among the workers belonging to new generations. Thus, I emphasize the significance of theorizing leadership processes of emerging leaders, while identifying their implications for organizations in managing new generations. 
Emerging Leadership at Operational Level: The Convergence of Self-and Social Construction of Leadership

\section{Emergence of Leadership}

Research studies that looked into the emergence of leadership are not new (Curtin 2004). They have theorized leadership emergence as either a lifelong process (Clinton 1989), at corporate level (Stadler 2009), in small groups (Curtin 2004), in virtual teams (Greer \& Jehn 2009), in self-managing teams (Wolff, Pescosolido \& Druskat 2002), in complex adaptive systems (Lichtenstein \& Plowman 2009), or at times of ambiguity (Pescosolido 2002). Despite these, the attempts that explored leader emergence at operational level in a larger crowd of workers (as in labor-intensive industries) seem to be sparse. However, the outcomes of the existing research studies help us with two streams of knowledge, that is: (1) the process of leader emergence, and (2) the characteristics of emerging leaders.

\section{Process of Leader Emergence}

Referring to a sequential developmental model in small group behaviour, (Tuckman 1965, Stein, Hoffman, Cooley, \& Pearse 1979) presented a valence model of emergent leadership, which was structured with three distinct stages of leadership emergence. At the 'orientation stage' (first stage), the potential leaders announce their candidacies; at the 'conflict stage' (second stage), two or more leaders pass the candidacy threshold causing a conflict; and at the 'emergence stage' (third stage), the group members willingly subordinate themselves to the leader who has passed the emergence threshold. This process incorporates the involvement of both the self and others in the emergence of leaders. The orientation stage shows the selfengagement of the emerging leader, while the emergent stage presents the involvement of others (group members) in embracing the leadership that emerges. The conflict stage shows competing behaviour among several emerging leaders who attempt to emerge from among themselves. Accordingly, this theorization focuses on the emergence of one individual for the leadership competitively by winning the hearts of fellow members. My theorization deviates from this in its consideration of the emergence of any number of possible leaders among a large number of operational level workers of the same work floor.

Curtin's (2004) investigation of emergent leadership, which validated the three stages theorized by Stein et al. (1979), was confined to the test of the role of jury foreperson's emergence and maintenance of leadership.

The leadership emergence theory (LET) developed by Clinton (1989) explicated three parallel processes in leadership development, which were termed: (1) internal psychological processes of the individual, (2) external sociological and contextual processes, and (3) divine processes. Even here, the involvement of both the self and others have been acknowledged. 
Clinton's (1989) theory is based on the premise that leadership emergence is a process in which 'God interferes throughout a lifetime in crucial ways to shape the leader towards His will' (p. 7). It is entirely focused on the development of Christian leaders. However, Stadler (2009) tested and validated this theory in the corporate environment with a focus on corporate leadership development.

\section{Characteristics of Emerging Leaders}

Pescosolido's (2002) theorization focuses on leader emergence at times of ambiguity. Thus, the role of managing group emotions by interpreting emotional response and modeling that response was highlighted as a major characteristic of emerging leaders. Pescosolido posits that emerging leaders are empathetic and responsive to follower needs and they rely on influence process. According to him, leader emergence is subject to several conditions such as degree of empathy, group norms of emotional expression, and ambiguous feedback regarding the group's performance. Wolff, Pescosolido, and Druskat (2002) proved that empathy enables emerging leaders the cognitive skill of pattern recognition and perspective taking, which form the base of leadership behaviour displayed by emergent leaders. However, their research focus was limited to leader emergence in self-managing teams.

Greer and Jehn (2009) investigated the strategies used by individuals in virtual environments to emerge as leaders. They found that the members who emerge as leaders rely more on soft influence tactics than hard and rational influence behaviours.

My theorization deviates from the research that dealt with the emergence of spontaneous or temporal leadership in group settings. Further, it is different from informal leadership (Pescosolido 2002, Wolff, Pescosolido \& Druskat 2002) but it will accommodate the view that emerging leadership can be initiated as informal leadership at the stage of self-construction, which is later embraced by followers, accepted by management, and empowered through appointments to formal leadership positions in the organization.

\section{Self- and Social Construction of Leadership: Implications from Leadership Literature}

In this section, I examine the implications given by leadership literature to identify the conceptual possibility of self- and social construction of leadership, in general. I first take up the self-construction part of leadership, and then proceed to the social construction part. A summary of implications as they lead to deriving the stages of the process of emerging leadership are given in Table 1, followed by the present discussion. 
Emerging Leadership at Operational Level:

The Convergence of Self-and Social Construction of Leadership

\section{Self-construction of Leadership}

The initial conceptualizations developed in leadership theory have been centered on 'leader' him/herself and thus have contributed immensely to understanding how individuals act towards constructing self as a leader. I here define the self-construction of leadership as 'the intentional and attempted development of self as a leader'. It would be activated through an inner drive (Maslow 1954, Luthans 2008) and through persuasion of others. As such, it is an act performed by individuals who have the desire, ability, and confidence to become leaders in the future. Hence, it is a performance of emerging leaders.

Individuals who possess certain exemplary traits or personalities (House \& Aditya 1977) would tend to emerge as leaders among a group of average people. Intelligence, knowledge, and experience above the average of the group (Judge, Colbert \& Illies 2004) could motivate an individual to proceed towards leading others. Further, the ability to influence others through their voice, clear communication, and opinions suggest the energy behind possible leader emergence. Well initiated and managed interactions among people, such as relations and transactions (Gerstner \& Day 1997), the ability to envision and initiate change in the form of transformation (Bass 1985, Burns 1978), and even charisma (Conger \& Kanungo 1987) would strengthen the individuals' emergence as leaders in work settings.

A rich requisite for the self-construction of leadership can be found in charismatic leaders. Behling and McFillen (1996) delineated some attributes of charismatic leader behaviour, which could be considered as a means of self-construction of leadership. They are: (1) showing concern for followers' needs, wants and fears (empathy), (2) articulating purpose through language (dramatization of the mission), (3) acting confidently and with certainty (protecting self-assurance), and (4) creating an impression of personal competence (enhancing one's own image).

Apart from those broad-based theories, recent literature focuses on more self-centric attributes of leaders. As such, authentic leadership which grasps the portrait of individuals "who are deeply aware of how they think and behave and are perceived by others as being aware of their own and others' values/moral perspectives, knowledge and strengths" and are "confident, hopeful, optimistic, resilient and of high moral character" (Avolio \& Gardner 2005, p. 321) implies 'authenticity' as an important aspect of self-construction of leadership. Thus, authenticity (or being true to self) and integrity (or being true to others) (Field 2007) can be seen as necessary grounds for self-construction of leadership. Sayles (1993) demonstrated how leaders make their role legitimized in the eyes of their followers. 


\section{NSBM Journal of Management}

Vol. 2, No. 1, January - June, 2016

Legitimizing leadership incorporates: (1) demonstrating superior ability, knowledge of the group norms, expectations and values, (2) acting as the group's spokesperson, protector and representative by helping solve problems of group members, (3) displaying self-confidence, successfully handling challenges, (4) showing persistence, etc. This notion can be adopted to see how prospective and emerging leaders attempt to construct their image to be reflected as qualifying to be leaders.

\section{Social Construction of Leadership}

Following the era of leader-centric theory development, the increasing interest in followership or the followers' role in developing leadership has led to leadership research. The followers' role in creating leaders is well demonstrated in the primary notion of leadership as it acknowledges that "leaders are those who have followers". As such, leaders cannot exist without followers, and it is the followers who create leaders. Thus, as suggested, the followers' constructive role in leadership cannot be underestimated. I here define the social construction of leadership as 'the intentional or unintentional embracing of individuals as leaders by others'.

Even though the notion of social construction of leadership is relatively new in leadership theory, such conceptualizations have appeared in recent literature (e.g., DeRue \& Ashford 2010, Field 2007, Meindl 1995).

Implicit leadership theories (ILTs) have been successful in explaining how personal assumptions about the traits and abilities of leaders create cognitive structures or schemas that followers expect to be seen in their leaders (Epitropaki \& Martin 2004, Lord \& Maher 1993, Offerman, Kenney \& Wirtz 1994, Phillips 1984). These cognitive structures or schemas are stored in human memory over time, which form individual perceptions and thus their interpretations of other people (Epitropaki \& Martin 2004). Such a perceptual process clearly implies a process that establishes the underlying predispositions of group members towards their prospective leaders.

Social identity theory (Turner \& Oakes 1986) helps us understand how leaders emerge through the 'matching' of such 'idealities' constructed by the group members with the norms, values, traits, and standards shown by the prospective leaders. Leader group prototypicality (van Knippenberg \& van Knippenberg 2005, van Knippenberg, van Knippenberg \& van Dijk 2000) explains this congruence and its mechanism that leads to the emergence of leaders. The 'prototypes' being the "abstract conception of the most representative members or 
Emerging Leadership at Operational Level: The Convergence of Self-and Social Construction of Leadership

most widely shared features of a given cognitive category" (Phillips 1984, p.126) facilitate the construction of leadership by means of interpersonal interactions, prior experiences of individuals held in mind, and exposure to various social events collectively (Epitropaki \& Martin 2004). As suggested in leadership categorization theory (Lord, Foti \& De Vader 1984), the people in groups are categorized as leaders on the basis of perceived prototypic attributes.

The view of the social construction of leadership has been further strengthened by the theory of romance of leadership (Meindl, Ehrlich \& Dukerich 1985). Meindl et al. (1985) who argue that leadership is a perception "that plays a part in a way people attempt to make sense out of organizationally relevant phenomena" (p. 79). It has drawn attention to the follower perception of leader's attributes especially in crises (Pillai 1996, Pillai \& Meindl 1998). It is apparent that social construction of leadership necessarily works on perceived (effective) leader performance by the followers. Thus, (effective) leader performance plays a pivotal role in that endeavor. Table 1 below summarizes the above theoretical implications and depicts the derivation of stages in the process of emerged leadership.

Table 1: Derivation of Stages in the Process of Emerged Leadership

\begin{tabular}{|c|c|c|c|}
\hline $\begin{array}{l}\text { Constructive } \\
\text { Dimension }\end{array}$ & $\begin{array}{l}\text { Theoretical Implications } \\
\text { of Leader Manifestation }\end{array}$ & $\begin{array}{l}\text { Leader / Follower } \\
\text { Functions in the } \\
\text { Constructive Process }\end{array}$ & $\begin{array}{l}\text { Stage in the Process of } \\
\text { Emerged Leadership }\end{array}$ \\
\hline \multirow{4}{*}{$\begin{array}{l}\text { Engagement of } \\
\text { self }\end{array}$} & Traits & Making impressions & Impressive engagement \\
\hline & Charisma & & \\
\hline & Communication & & \\
\hline & Authenticity & & \\
\hline \multirow[t]{3}{*}{$\begin{array}{l}\text { Leader } \\
\text { performance }\end{array}$} & Achieving targets & $\begin{array}{l}\text { Symbolizing } \\
\text { effectiveness }\end{array}$ & $\begin{array}{l}\text { Symbolized } \\
\text { effectiveness }\end{array}$ \\
\hline & Successful influence & & \\
\hline & Healthy relations & & \\
\hline \multirow[t]{2}{*}{ Leader idealities } & Implicit theories & $\begin{array}{l}\text { Narrating visual } \\
\text { performance }\end{array}$ & Follower narration \\
\hline & Leader prototypes & & \\
\hline $\begin{array}{l}\text { Leader } \\
\text { acceptance }\end{array}$ & Romancing leadership & $\begin{array}{l}\text { Embracing emerged } \\
\text { leadership }\end{array}$ & $\begin{array}{l}\text { Collective embracing of } \\
\text { emerged leadership }\end{array}$ \\
\hline
\end{tabular}


NSBM Journal of Management

Vol. 2, No. 1, January - June, 2016

\section{A Model of Self- and Social Construction of Leadership}

Recently there has been growing attention to the social processes that construct leadership in organizations (e.g., Bresnen 1995, Uhl-Bien 2006, Valcea, Hamdani, Buckley \& Novicevic 2011). However, researchers have shown little interest in the social processes through which leadership emerges at the operational level of work organizations. In this paper, I propose that leadership among co-workers at operational level in work organizations emerges in a process of self-construction (of emerging leaders) and social construction (of co-workers or followers).

\section{Leadership that Emerges Defined}

The term 'emerge' is derived from the Latin term émergene, carrying the meaning 'to rise from', 'to become known', 'to become evident', 'to become manifest', 'to come into existence' or 'to come forth from obscurity' (The American Heritage Dictionary 2013, Merriam-Webster Dictionary 2013). Considering this connotation, I define 'leadership that emerges' as 'the leadership that becomes manifest from among a constellation of co-workers through the impressive engagement of individuals followed by collective acceptance by others'.

As presented in Figure 1, I propose that impressive engagement of individuals and their symbolized positive performance (which form the self-construction of leadership), and follower narration and collective embracing of the leadership that emerges (which form the social construction of leadership) are the underlying processes of leadership that emerges among operational level workers in organizations.

Figure 1: The Process of Self- and Social Construction of Emerged Leadership

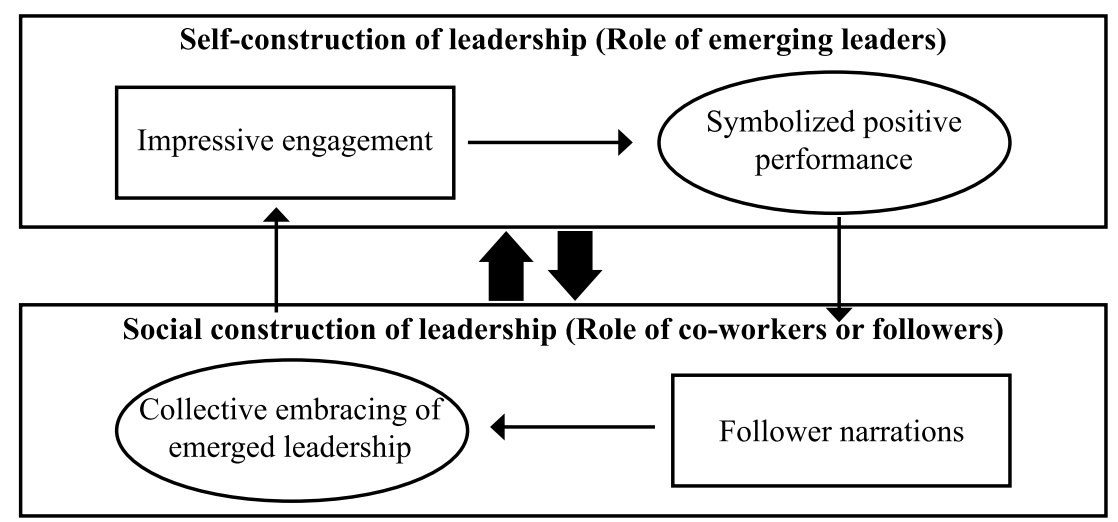


Emerging Leadership at Operational Level: The Convergence of Self-and Social Construction of Leadership

\section{Methods}

I employed the case study strategy (Yin 2009) to study the process of self-and social construction of leadership that emerges among operational level workers in a labor-intensive industry. This case study was conducted as part of a comprehensive study, which attempted to report the successful management practices used to manage young workers in a textile company in Sri Lanka. It found the evidence of emerging leadership at the lower level, which was subsequently accepted by peer workers. The findings of the study suggested that leadership of young workers at operational level emerges in a process of active selfconstruction performed by themselves and the social construction followed and evidenced by their co-workers or followers.

\section{Research Setting}

The textile and clothing industry is a highly labour-intensive and low-wage industry yet considered as a dynamic and innovative sector. It has been an important source of employment, offering entry-level jobs for non-skilled and semi-skilled labour, especially in developing countries (Nordas 2004). The easy adaptation of relatively modern technology at relatively low investment costs has encouraged developing countries to step into this industry and make a substantial contribution to GDP. The textile industry has become the major input provider to the clothing industry thus creating a vertical supply chain. Accordingly, the key success variables of the textile industry some of which are noted as cost effectiveness, high quality of products, meeting demand targets. While the factors enabling competitive advantage include access to quality inputs, uninterrupted production process, reliability of delivery and continuous improvements in the entire process.

The case organization is a (recently listed) public limited company in the textile industry operating from 2001 in Sri Lanka. It manufactures and supplies a variety of designs and specifications of weft knitted fabrics for garment manufacturers and apparel brand owners worldwide. The company is situated in an industrial zone located approximately two hours' drive from the capital city.

The total employment was 1,220, which comprised managers, assistant managers, executives, staff, and associates. Seventy percent of employees were 'associates' employed at operational level. Table 2 below depicts the employment categories in the organization. 
NSBM Journal of Management

Vol. 2, No. 1, January - June, 2016

Table 2: Composition of Total Workforce

\begin{tabular}{lcc}
\hline Category & Number & Percentage \\
\hline Managers & 06 & 0.5 \\
Assistant Managers & 25 & 2.5 \\
Executives & 149 & 12 \\
Staff & 187 & 15 \\
Associates & 853 & 70 \\
\hline
\end{tabular}

Source: Survey data (2011)

Ninety-three percent of the associates fall between 18 and 35 years of age. Ninety-five percent of associates were males, and 76.5 percent were unmarried. See Table 3 below for a simple demographic profile of the associates.

Table 3: Demographic Profile of Associates

\begin{tabular}{llc}
\hline Characteristic & & Percentage \\
\hline Gender: & Male & 95 \\
& Female & 05 \\
Civil status: & Married & 23.5 \\
& Single & 76.5 \\
Age category: & $18-24$ & 41 \\
& $25-34$ & 52 \\
& Above 35 & 07 \\
\hline
\end{tabular}

Source: Survey data (2011)

\section{Data Collection Protocol}

Personal visits to the organization enabled the collection of primary and secondary data through a variety of sources: interviews and discussions held with operational level workers and managerial staff, and examination of archival data. Data collection ended at the point of saturation of evidence (Eisenhardt 1989) where the same evidence seemed to be repeated. The major sources of data are described below.

A series of semi-structured interviews employing a set of open-ended questions was held with operational level workers (associates) and a team of joint consulting committee (JCC) members. The focal point of the investigation was "How leaders emerged at operational level". The search effort was driven in two directions: (1) the actions taken by emerging 
Emerging Leadership at Operational Level:

The Convergence of Self-and Social Construction of Leadership

leaders, and (2) the rationale behind their emergence as leaders. Accordingly, the questions used for probing into the main theme emanated and revolved around the following areas: (1) taking up of formal and informal assignments at work, (2) achieving targets, (3) representing the work group, (4) motivation to lead the group, and (5) organizational facilitation for taking the lead in a group.

The interviews were continued until the marginal contribution to the database became smaller.

Further, a few interviews and discussions were held at the organization premises with a representative from senior management. Four personnel from middle management, representing human resource, quality control, production and operations and accounting were interviewed separately. The interviews used a semi-structured and open-ended questionnaire for probing broadly into the company arrangements for leadership development.

The internal documents covering organization structure, worker demography, performance indicators, achievements and awards, and the records of employee achievements were examined for cross verification. In addition to these, the magazine of events published by the organization, and the home page of the organization were used as secondary data sources. Using research questions for probing and interview guides and prior-designed instruments for gathering data confirmed the methodological rigour (Eisenhardt 1989). The present study used multiple sources of evidence and member checking (Yin 2009) for ensuring the rigour and reliability of collected data.

\section{Analysis of Data}

All narratives for unveiling "How leaders emerge at the operational level" were carefully documented and reviewed for identifying the underlying themes. Patterning and evaluating (Yin 2009), followed by several reading rounds helped categorizing three facets, which were connoted in the investigation as: (1) what do operational level workers do to emerge as leaders among their peers? (2) how do they emerge as leaders? and (3) why do they emerge as leaders from among their peers? Subsequently, a thematic analysis highlighted two underlying themes in the present study, which explained the construction of the leadership that emerged at operational level: (1) performing and achieving (by emerging leaders), and (2) narrating and accepting (by followers or peers). 
NSBM Journal of Management

Vol. 2, No. 1, January - June, 2016

\section{Emerging Leadership among Operational Level Workers}

The findings of the study suggest a demarcation of two stages in leadership emergence among operational level workers, the first stage being their own attempt to emerge as leaders and the second stage embracing of leaders by their co-workers or followers. Thus, it led to identifying the self-construction and social-construction of leadership among operational level workers as discussed below. Table 4 below depicts the empirical evidence supporting the process of emerged leadership as found in the study.

Table 4: Empirical Evidence Supporting the Process of Emerged Leadership

\begin{tabular}{|c|c|c|c|}
\hline $\begin{array}{l}\text { Constructing } \\
\text { Phase }\end{array}$ & $\begin{array}{l}\text { Leader/Follower } \\
\text { Functions in the } \\
\text { Constructive Process }\end{array}$ & $\begin{array}{l}\text { Empirical Evidence } \\
\text { of Leader/Follower } \\
\text { Manifestation }\end{array}$ & $\begin{array}{l}\text { Stage in the Process of } \\
\text { Emerged Leadership }\end{array}$ \\
\hline \multirow[t]{4}{*}{ Self } & $\begin{array}{l}\text { Active engagement in } \\
\text { extra-work arrangements }\end{array}$ & Event organizer & Impressive engagement \\
\hline & $\begin{array}{l}\text { Self-appointment for } \\
\text { positions }\end{array}$ & Team leader & \\
\hline & Role model behavior & Fluent communicator & \\
\hline & $\begin{array}{l}\text { Cooperation with } \\
\text { management }\end{array}$ & JCC member & \\
\hline \multirow[t]{2}{*}{ Self } & $\begin{array}{l}\text { Achieving management- } \\
\text { given targets }\end{array}$ & Award winner & $\begin{array}{l}\text { Symbolized } \\
\text { effectiveness }\end{array}$ \\
\hline & $\begin{array}{l}\text { Cooperating with } \\
\text { colleagues in performing }\end{array}$ & Peer facilitator & \\
\hline \multirow[t]{3}{*}{ Follower } & $\begin{array}{l}\text { Narrating role model } \\
\text { behavior }\end{array}$ & Lunch-time narrations & Follower narration \\
\hline & Appraising cooperation & Praising publicly & \\
\hline & $\begin{array}{l}\text { Appraising empathy/help/ } \\
\text { emotional support }\end{array}$ & Showing gratitude & \\
\hline \multirow[t]{3}{*}{ Follower } & Group support & $\begin{array}{l}\text { Help in leadership } \\
\text { endeavors }\end{array}$ & $\begin{array}{l}\text { Collective embracing of } \\
\text { emerged leadership }\end{array}$ \\
\hline & Group acceptance & $\begin{array}{l}\text { Appreciating } \\
\text { leadership }\end{array}$ & \\
\hline & Creation of followership & $\begin{array}{l}\text { Gather under emerged } \\
\text { leadership }\end{array}$ & \\
\hline
\end{tabular}

\section{Self-construction of Leadership by Operational Level Workers}

Findings from multiple sources provided evidence of the fact that young operational level workers of the case organization are encouraged by the organization to emerge as leaders by 
Emerging Leadership at Operational Level:

The Convergence of Self-and Social Construction of Leadership

themselves and that the individual workers who exploit these opportunities make further attempts to impress their co-workers and the management through certain actions throughout their early work life. Two major catalysts were visible in this process: (1) impressive engagement, and (2) symbolized positive performance of young workers.

\section{Impressive engagement}

Goffman (1959) theorized about the actions of people in their everyday life in different roles in constructing their social identities. The theory of impression management suggests that people seek to manage images others have of them, and such images create social identities, which influence the perceptions and behaviors of others by controlling the information they receive (Rosenfeld, Giacalone \& Riordan 1995). Thus, people consciously control impression management behaviours. As such, managing impressions helps people achieve their intended goals and objectives in their daily life and work life.

Recent developments in leadership theory show new directions towards leader appointments, questioning the traditional superior centred power in contemporary and shared internal cultures. Thus, enabling leadership (Falk \& Mulford 2001) and community leadership (Ehrich, Lisa \& Creyton 2010) have appeared to theorize such developments. Highlighting the need for event level analyses of leader emergence, Dinh and Lord (2012) posit that people tend to emerge as leaders in different events. A top management representative revealed how associates get opportunities in usual work settings to show up their emergence in situations.

Whenever there are informal gatherings and CSR work proposed by the Company, we don't hand-pick people to lead the group. I just pass the message, they all do it. It is they who decide who takes the initiative and who does what... [DGM/HR \& Admin]

The findings of the present study reveal the instances which opened up opportunities for operational level workers to create and manage impressions on others, and how they have successfully exploited such opportunities during their usual work life. It was revealed through several means such as discussions, interviews, wall notices, and news bulletins that not only day-to-day routine and formal work arrangements but also out-of-job and informal event arrangements are made available by the organizational management on many occasions. These occasions provided ample opportunities for young emerging leaders to take the lead and show up their command and competency in making others follow. The following is an example noted from the deliberation of an associate: 


\section{NSBM Journal of Management}

Vol. 2, No. 1, January - June, 2016

We love the way they give us the freedom to organize things at the Company. Once we were asked to get ready for a 'well-cleaning' in a faraway rural area. We two-three boys arranged everything at ground level. Sirs were very happy; they accompanied us to the place and provided all facilities. It was a nice experience. We followed the same way as we did for 'labor donations' for many such events. There are always a few in the group who take the initiative and give guidance for all...

The present case of young operational level workers, who were ambitious enough to emerge as leaders among a crowd of co-workers, suggested that impression management theory levels the ground to look into how they create and manage impressions of others through their 'impressive engagement' in the workplace. Two associates testified as follows:

I love to take the lead. I do my best every time in that. I have been into that from my village school time... [Associate]

Somebody should take the lead; otherwise we cannot work as a group. So, I like to impress my brothers when I get the time... [Associate]

Thus, the imperative behaviour shown by them in order to emerge as leaders could be seen as impressive engagement in such arrangements. Accordingly, the above knowledge leads to the following proposition:

Proposition 1: Impressive engagement in formal and informal activities in organizations is a distinguishable behaviour shown by emerging leaders at operational level.

\section{Symbolized Positive Performance}

Motivation theories explain how the inner drive of an individual would lead to higher performance and achievement of goals (e.g., Deci \& Ryan 1985; Vroom 1965). Especially, the expectancy theory (Vroom 1965) posits the link between individual expectations and work outcomes. More precisely, the theory of self-fulfilling prophecy (Merton 1948) explicates the association between individual expectation and followed outcomes on positive grounds. Rosenfeld et al. (1995) indicated that individuals impress not only the external audience but also the internal audience; that is self. Thus, theoretically, managing impressions itself becomes a self-fulfilling prophecy, and in turn predicts higher work performance. 
The findings at the case organization revealed that impressively engaged young workers were the recorded annual award winners of the organization. Further, the associates who had been promoted to executive and managerial grades in their career were those who exhibited outstanding performance at work and impressively engaged in organizing the informal events in the organization. It was further noted that the workers who were competent enough to impress the others were accepted as representatives of the JCC, and resultantly they were identified by the management and considered for formal leader positions in the work organization. As we probed into the individual sensations of the workers about the results of such impressive engagements, the following statement was heard:

If we are ourselves and do our best at our level, we always get the result for that. You will see who have won the 'best worker award', 'half-sovereign' and 'one sovereign' awards annually... [Associate]

Based on the logic in the existing knowledge and the evidence of the reality, I propose that impressive engagement of operational level workers would result in symbolized positive performance at work organization. Thus, I propose that

Proposition 2: Impressive engagement of emerging leaders at operational level will be positively related to their symbolized positive performance at work organization.

However, there can be certain instances when an emerging leader would be set back in showing splendid positive performance at work due to some reasons. It was observed in the field that the majority of workers are not passive followers. However, their active engagement was not as visible as that of those who were trying to be smart at certain formal and informal gatherings at the workplace. This was revealed by an associate who did not claim that he did well, but proclaimed his repeated attempts to perform better in team work that was arranged for a 'labour donation' (shramadana) at the three-wheeler park of the public transport area of the Company. In addition to this, another associate mentioned,

I was a team leader at our annual field trip last year. This time my friends are doing better. I too support them with my full capacity [Associate]

With this indication, and in line with expectancy theory, and with the support of the selfefficacy theory (Bandura1997) it would be reasonable to propose their re-attempted impressive engagement as emerging leaders even after previous failures. A repetitive failure 
would suggest their withdrawal from emerging as leaders. Accordingly, I propose the following proposition:

Proposition 3: Any failure in symbolizing positive performance by emerging leaders at operational level will lead to either their impressive engagement re-attempt (positive self-perception) or disengagement (negative self-perception)

\section{Social Construction of Leadership by Operational Level Workers}

The process of constructing leaders by their followers shows its theoretical basis in several theories and concepts that appear in the existing literature.

\section{Follower Narration}

Field (2007) posits that the cognitive models of leaders created through information processing by followers could be influenced by prospective leaders themselves or by contextual factors. Based on the Weighted Average Model (WAM) of follower perceptions of a leader's authenticity and integrity, Field (2007) elaborates on six factors that affect the follower perception of a leader. These factors can be seen as the building blocks of the social construction of leadership by followers. They are: (1) the number of follower observations of leader actions and interactions to gauge leader motives, (2) multiple followers observe the same actions of the leader and gather similar information about motives, (3) the stability of the leader's behaviour and motives across instances, (4) similarity in follower interpretations of leader actions and underlying motives, (5) extraneous information about the leader available to followers, and (6) communication among followers concerning the leader, the situation, and leader motives (p.199).

The field survey data brought out evidence of public praise of certain vigilant behaviors of the emerging leaders by their peer followers. Most of such instances were related to important incidents such as achieving targets, sending messages to management, planning informal events, etc., where they had displayed exemplary performance. It was noted that many peer associates at the interviews repeated the same set of names of peers emerging as leaders for their outstanding performances. One informant stated,

Our own friends have become role models to us. They make our day easy at work. They are being appreciated by the management too. We are proud of them. We admire our peer leaders and love to praise them in all our formal and informal forums... [Associate] 
Emerging Leadership at Operational Level: The Convergence of Self-and Social Construction of Leadership

Apparently, the followers' expressions of gratitude, viewing emerging leaders as role models, praising the empathy shown and the emotional support provided by emerging leaders signaled the contagion of positive attitude towards emerging leaders among peer followers. The natural flow of expressions about the superior performance of their peer workers itself endorsed the habit of follower narration about emerging leaders. This recognition leads to the following proposition:

Proposition 4: Symbolized positive performance of emerging leaders at operational level is positively related to follower narrations about emerging leaders

\section{Collective Embracing of Emerging Leadership}

Organizational members throughout their lives in organizations continuously make sense (Weick 1995) of the incidents, events, work processes, relationships and behaviours enacted in the work environment. This sense-making process is further enabled in organizational socialization (Epitropaki \& Martin 2004) and enriched by the collective (past) experiences of organizational members. Thus, the opportunities for interaction, communication, and teamwork (Balkundi \& Kilduff 2005) enhances members' making sense of the traits, values, behaviors, competencies, and expertise of their colleagues in the work teams or groups. Interactive communities in work organizations (Fairholm 1996) collectively construct the objectively perceived realities based on their subjectively held perceptions in their individual minds (Burger \& Luckmann 1966). Thus, team work arrangements, collective engagement, collective assignments all provide ample opportunities for organizational members to collectively identify and agree upon the individuals who they want to be their leaders. Leadership is a negotiated process, and people tend to grant leadership to others at different events (Dinh \& Lord 2012). Story-telling and narratives have been mechanisms through which people construct meanings collectively in organizations (Brown 1986).

Identifying emerging leaders as role models, heroes, or saviours on particular occasions at the case organization, proved the acceptance of the leader role by peer followers in the given scenario. Seemingly, stories and narratives shared at work about the exemplary behaviour of emerging leaders of the group had led to this social acceptance.

Proposition 5: Follower narrations are positively related to collective embracing of emerged leadership by followers at operational level 


\section{NSBM Journal of Management}

Vol. 2, No. 1, January - June, 2016

Leadership is a social exchange (Bass 2008). Velca et al. (2011), examining the leaderfollower interactions and development of meaning-making systems by each of the other parties, posit that both leaders and followers help promote leader development. Sparrowe (2005) emphasized the role played by others through the narrative process in creating authenticity in leadership. As evidenced in the examined case too, followers' public narrations and acceptance of emerging leaders collectively suggest the strengthening of leaders' self-construction efforts. Similarly, on the other hand, the self-construction efforts of emerging leaders (such as impressive engagement and symbolized performance), perceived by followers, seem to open more avenues for follower narrations and acceptance. Thus, I propose the following:

Proposition 6: Collective embracing of emerging leadership leads to strengthening the impressive engagement of emerging leaders at operational level.

As evidenced in the theoretical basis of this study (e.g., Avolio \& Gardner 2005, Behling and McFillen 1996, Field 2007, Sayles 1993) and the field data, the individual attempt of emerging leaders in impressive engagement and consequent symbolized positive performance together strengthen their self-construction of leadership. As indicated in the theorizations on cognitive structure of followers (e.g., Epitropaki \& Martin 2004, Lord \& Maher 1993), and leader group pro-typicality (e.g., van Knippenberg \& van Knippenberg 2005, van Knippenberg, van Knippenberg \& van Dijk 2000), it becomes evident that self-level leader actions enable social-level cognitive constructions of followers. This leads to thinking that individual selfconstructions of leaders become sensible in the eye of the followers, which in turn helps to construct their narrations and subsequent behaviour of embracing emerging leadership. As these self and social processes take place on different platforms, it becomes clear that selfconstruction of leadership by emerging leaders at individual level leads to strengthening the social construction of leadership by followers. Accordingly, I add the following two propositions to my theorization.

Proposition 7: The self-construction of emerging leadership will lead to the social construction of emerging leadership.

Proposition 8: The social construction of emerging leadership will strengthen the selfconstruction of emerging leadership. 
Emerging Leadership at Operational Level: The Convergence of Self-and Social Construction of Leadership

\section{Conclusion and Implications}

The present study examined how leadership emerges in a group of co-workers at the operational level. It proposed the convergence of self- and social construction of emerged leadership at the operational level through a process of impressive engagement, symbolized positive performance, follower narrations, and collective embracing of emerging leadership. This theorization offers a cluster of implications for HR managers, leader trainers, organizational line managers, and theorists.

\section{Practical implications}

Emerging leaders are identifiable through impressive engagement and symbolized positive performance at work. Accurate recognition of impressive engagement of operational level workers will ease the identification of effective opinion leaders and active representatives. This may strengthen worker-management co-operation thus leading to reducing worker unrest and industrial conflicts. Similarly, this would be an indication of a possible chance for worker dissatisfaction, in case of failure of such recognition. This study further indicates the line managers' responsibility for opening appropriate avenues for operational level workers to emerge as leaders and their peer workers or followers to freely narrate the prototypes of their prospective leaders.

The awareness of individual behaviours of operational level workers in line with this process facilitates selecting socialization agents for new recruits. Deployment of emerging leaders on appropriate occasions may help reduce any possible workplace deviant behavior that could come out among operational level workers.

As implied here, the sensitivity of organizational management (both line and HR) to the process of self- and social construction of leadership would result in many benefits in their HR-related processes and decisions and performance management processes and decisions.

\section{Theoretical Implications}

The present theorization can be extended to several areas. First, an empirical examination of specific activities performed by emerging leaders in managing the impressions others have of them would provide more insights into leader emergence at this level. Similarly, the empirical test and theorization of specific activities performed by peer workers or followers in embracing the emerging leadership may be extended to the social construction viewpoint in leadership as well as followership behaviour at work. Further, the intrapersonal or cognitive 


\section{NSBM Journal of Management}

Vol. 2, No. 1, January - June, 2016

processes of self-construction of leadership have to be investigated at deeper levels, thus unveiling any other possible construction at the self-level from a psychological viewpoint. Finally, the individual and organizational outcomes of the failures of the leader emergence process are noted as worthy of further investigation.

This study used a single case limited to a labour-intensive industry. Despite the critiques levelled against the use of single case studies for generalization purposes (Eisenhardt 1991), the present study typifies the organizational behaviour in a homogeneous group of young lower level workers in this particular industry. This homogeneity accumulates through the similarity of their age group (majority belonging to age between 18-24), area of origin and dwelling (rural), semi-skilled or unskilled character of labour at recruitment, and thus the level of exposure to the outside world of life and work. However, leader emergence at operational level in other industrial settings, where these characters differ in a workforce, may need investigation. Testing the suggested propositions in future studies would strengthen the current theorization while indicating further directions for theory development in emerging leadership.

\section{References}

Avolio, BJ \& Gardner, WL 2005, 'Authentic leadership development: getting to the root of positive forms of leadership', The Leadership Quarterly, vol.16, pp. 315-338.

Balkundi, P\& Kilduff, M 2005, 'The ties that lead: a social network approach to leadership', The Leadership Quarterly, vol. 16, no. 6, pp. 941-961.

Bass, BM 1985, Leadership and performance beyond expectations, Free Press, New York.

Bass, BM 2008, Bass \& Stogdill's handbook ofleadership theory, research, and managerial applications, (3rd ed.), The Free Press, New York, pp.319-361.

Behling, O \& McFillen, JM 1996, 'A syncretic model of charismatic/transformational leadership', Group and Organization Management, vol. 21, no. 2, pp. 163-191.

Berger, PL \& Luckmann, T 1966, The social construction of reality: a treatise in the sociology of knowledge, Doubleday, Garden City, NY.

Bresnen, MJ 1995, 'All things to all people? Perceptions, attributions, and constructions of leadership', The Leadership Quarterly, vol. 6, pp. 495-513.

Brown, MH 1986, 'Sense making and narrative forms: reality construction in organizations', in L. Thayer (Ed.), Organizational Communication: Emerging Perspectives I, Albex, Norwood, NJ, pp. 7184.

Burns, JM 1978, Leadership, Harper \& Row, New York. 
Carson, JB, Tesluk, P E, \& Marrone, JA 2007, 'Shared leadership in teams: an investigation of antecedent conditions and performance', Academy of Management Journal, vol. 50, no. 5, pp. 1217-1234.

Carsten, MK, Uhl-Bien, M, West, BJ, Patera, JL \& McGregor, R 2010, 'Exploring social constructions of followership: a qualitative study', The Leadership Quarterly, vol. 21, pp. 543-562.

Carucci, RA \& Epperson, JJ 2011, 'Bridging the leadership divide: forging meaningful relationships between generations of leaders', Journal of Leadership Studies, vol. 5, no. 3, pp. 63-71.

Clinton, JR 1989, Leadership emergence theory: a self-study manual for analyzing the development of Christian leaders, Barnabas, Altadena, CA.

Conger, JA \& Kanungo, RN 1987, 'Toward a behavioral theory of charismatic leadership in organizational settings', Academy of Management Review, vol. 12, pp. 637-647.

Conger, JA \& Kanungo, RN1998, Charismatic leadership in organizations, Sage, Thousand Oaks, CA.

Curtin, JL 2004, 'Emergent Leadership: case study of a jury foreperson', Leadership Review, vol. 4, pp. $75-88$.

Dasborough, MT, Ashkanasy, NM, Tee, EYJ \& Tse, HHM 2009, 'What goes around comes around: how meso-level negative emotional contagion can ultimately determine organizational attitudes toward leaders', The Leadership Quarterly, vol. 20, pp. 571-585.

Deci, EL \& Ryan, RM 1985, Intrinsic motivation and self-determination in human behavior. Plenum Press, New York, NY.

Derou, DS \& Ashford, SJ 2010, 'Who will lead and who will follow? A social process of leadership identity construction in organizations', Academy of Management Review, vol. 35, pp. 627-647.

Dinh, JE \& Lord, RG 2012, 'Implications of dispositional and process views of traits for individual difference research in leadership', The Leadership Quarterly, vol. 23, pp. 651-669.

Ehrich, Lisa C \& Creyton, M 2010, 'Leading with moral purpose: insights from community leaders', in 5th International Conference on Catholic Educational Leadership, 2-4 August 2010, Sydney.

Epitropaki, O \& Martin, R 2004, 'Implicit leadership theories in applied settings: factor structure, generalizability and stability over time', Journal of Applied Psychology, vol. 89, pp. 293-310.

Eisenhardt, KM 1989, 'Building theories from case study research', Academy of Management Review, vol. 14 , no. 4 , pp. 532-550.

Eisenhardt, K M 1991, 'Better stories and better constructs: the case for rigor and comparative logic', Academy of Management Review, vol. 16, no. 3, pp. 620-627.

Falk, IH \& Mulford, WR, 2001, ‘Enabling leadership: a new community leadership model”, in I.H. Falk (ed.) Learning to manage change: developing regional communities for a local-global millennium, National Centre for Vocational Education Research Ltd, South Australia: Leabrook, pp. 215-224.

Fairholm, GW 1996, 'Spiritual leadership: fulfilling whole-self needs at work', Leadership \& Organization Development Journal, vol. 17, no. 5, pp. 11-17.

Fiedler, FE 1967, A theory of leadership effectiveness, McGraw-Hill, New York.

Field, DL 2007, 'Determinants of follower perceptions of a leader's authenticity and integrity', European Management Journal, vol. 25, no. 3, pp. 195-206. 


\section{NSBM Journal of Management}

Vol. 2, No. 1, January - June, 2016

Galvin, PM, Balkundi, P \& Waldman, DA 2010, 'Spreading the word: the role of surrogates in charismatic leadership processes', Academy of Management Review, vol. 35, pp. 477-494.

Goffman, E 1959, The presentation of self in everyday life, Doubleday Anchor, New York.

Gerstner, CR \& Day, DV 1997, 'Meta-analytic review of leader-member exchange theory: Correlates and construct issues', Journal of Applied Psychology, vol. 82, no. 6, pp. 827-844.

Greer, LL \& Jehn, KA 2009, 'Follow me: strategies used by emergent leaders in virtual organizations”, International Journal of Leadership Studies, vol. 5, pp. 102-120.

Hannah, ST, Walumbwa, FO \& Fry, LW 2011, 'Leadership in action teams: team leader and members' authenticity, authenticity strength, and team outcomes", Personnel Psychology, vol. 64, pp. 771-802.

House, RK 1971, 'A path goal theory of leader effectiveness', Administrative Science Quarterly, vol. 16, no. 03, pp. 321-339.

House, RJ \& Aditya, RN 1997, 'The social scientific study of leadership: quo vadis' Journal of Management, vol. 23, pp. 409-473.

Joshi, A, Dencker, J \& Franz, G 2011, "Generations in organizations", Research in Organizational Behavior, vol. 31, pp. 177-205.

Judge, TA, Colbert, AE \& Ilies, R 2004, 'Intelligence and leadership: a quantitative review and test of theoretical propositions', Journal of Applied Psychology, vol.89, pp. 542-552.

Kark, R \& van Dijk, D 2007, 'Motivation to lead, motivation to follow: the role of the self-regulatory focus in leadership processes', Academy of Management Review, vol. 32, no. 2, pp. 500-528.

Kerr, S, Schriesheim, CA, Murphy, C J \& Stogdill, RM 1974, 'Toward a contingency theory of leadership based upon the consideration and initiating structure literature', Organizational Behavior and Human Performance, vol. 12, pp. 62-82.

Küpers, W 2007, 'Perspectives on integrating leadership and followership', International Journal of Leadership Studies, vol. 2, no. 3, pp.194-221.

Lichtenstein, B \& Plowman, D 2009, 'The leadership of emergence: a complex systems leadership theory of emergence at successive organizational levels', Leadership Quarterly, vol. 20, pp. 617-630.

Lord, RG, Foti, RJ \& DeVader, CL 1984, 'A test of leadership categorization theory: internal structure, information processing, and leadership perceptions', Organizational Behavior and Human Performance, vol. 34, pp. 343-378.

Lord, RG \& Maher, KJ 1993, Leadership and information processing. Linking perceptions and performance. Routledge, London.

Luthans, F 2008, Organizational behaviour, 11th edn., McGraw-Hill International Edition, Singapore.

Maslow, Abraham H 1954, Motivation and personality, Harper \& Row, New York.

Mattis, MC, Gerkovich, PR, Gonzales, R, \& Johnson, NH 2004, 'Work related values and experiences of Generation X professionals and managers', in R.J. Burke and C. Cooper (eds.), Leading in Turbulent Times, Blackwell, Oxford, pp. 121-142.

Meindl, JR 1995, "The romance of leadership as a follower-centric theory: a social constructionist approach", The Leadership Quarterly, vol. 6, pp. 329-341. 


\section{Emerging Leadership at Operational Level: \\ The Convergence of Self-and Social Construction of Leadership}

Meindl, JR, Ehrlich, SB \& Dukerich, JM 1985, 'The romance of leadership', Administrative Science Quarterly, vol. 30, pp. 78-102.

Merriam-Webster Dictionary, viewed 15 November 2013, http://www.merriam-webster.com/dictionary/ emerge.Merton, RK 1948, 'The self-fulfilling prophecy', Antioch Review, vol. 8, pp. 193-210.

Mhatre, K H \& Conger, J A2011, "Bridging the gap between Gen X and Gen Y", Journal of Leadership Studies, vol. 5, no. 3, pp. 72-76. doi:10.1002/jls.20235

Mintzberg, H 1979, The structuring of organizations: a synthesis of the research, Prentice-Hall, Englewood, Cliffs, NJ.

Offermann, LR, Kennedy, JK \& Wirtz, PW 1994, 'Implicit leadership theories: content, structure, and generalizability', Leadership Quarterly, vol. 5, pp. 43-58.

Penney, SH \& Neilson, PA 2010, Next Generation Leadership: insights from emerging leaders, Palgrave Macmillan, New York.

Pescosolido, AT 2002, 'Emergent leaders as managers of group emotion', The Leadership Quarterly, vol.13, pp. 583-599.

Phillips, JS 1984, 'The accuracy of leadership ratings: a cognitive categorization perspective", Organizational Behavior and Human Performance, vol. 33, pp. 125-138.

Pillai, R 1996, 'Crisis and the emergence of charismatic leadership in groups: an experimental investigation', Journal of Applied Social Psychology, vol. 26, pp. 543-562.

Pillai, R \& Meindl, JR 1998, 'Context and charisma: a "meso" level examination of the relationship of organic structure, collectivism, and crisis to charismatic leadership', Journal of Management, vol. 24, pp. 643-671.

Rosenfeld, P, Giacalone, RA \& Riordan, CA 1995, Impression management in organizations:theory, measurement, practice, Routledge, London.

Sayles, LR 1993, The Working Leader, The Free Press, New York.

Sparrowe, RT 2005, 'Authentic leadership and the narrative self', The Leadership Quarterly, vol. 16, pp. 419-439.

Stadler, A 2009, 'Leadership emergence theory in the corporate context', International Journal of Leadership Studies, vol. 5, no. 1, pp. 115-122.

Stein, RT, Hoffman, LR, Cooley, SJ \& Pearse, RW 1979, 'Leadership valence: modeling and measuring the process of emergent leadership', in JG. Hunt \& LL Larson (Eds.), Crosscurrents in Leadership. Carbondale, Southern Illinois University Press, IL.

Stogdill, RM 1974, Handbook of leadership: a survey of the literature, Free Press, New York.

Super, DE 1957, Psychology of careers. Harper \& Brosna, York.

The American Heritage Dictionary, 2013, Haughton Mifflin, USA.

Tuckman, BW 1965, 'Developmental sequence in small groups', Psychological Bulletin, vol. 63, pp. 384-399. 


\section{NSBM Journal of Management}

Vol. 2, No. 1, January - June, 2016

Turner, JC \& Oakes, PJ 1986, 'The significance of the social identity concept for social psychology with reference to individualism, interactionism and social influence', British Journal of Social Psychology, vol.25, no. 3, pp. 237-252.

Uhl-Bien, M 2006, 'Relational leadership theory: exploring the social processes of leadership and organizing', The Leadership Quarterly, vol. 17, pp. 654-676.

Uhl-Bien, M, Marion, R\& McKelvey, B 2007, 'Complexity leadership theory: shifting leadership from the industrial age to the knowledge era', The Leadership Quarterly, vol. 18, pp. 298-318.

Van Knippenberg, B \& van Knippenberg, D 2005, 'Leader self-sacrifice and leader effectiveness: the moderating role of leader prototypicality,' Journal of Applied Psychology, vol. 90, no. 1, pp. 25-37.

Van Knippenberg, D, van Knippenberg, B \& van Dijk, E 2000, 'Who takes the lead in risky decision making: effects of group members risk preferences and prototypicality", Organizational Behavior and Human Decision Processes, vol.83, no.2, pp. 213-234.

Valcea, S, Riaz, M, Hamdani, MR, Buckley, M R \& Novicevic, MM 2011, 'Exploring the developmental potential of leader-follower interactions: a constructive-developmental approach', The Leadership Quarterly, vol.22, pp. 604-615.

Vroom, VH 1965, Motivation in management, American Foundation for Management Research, New York, NY.

Weick, KE 1995, Sensemaking in organizations, Sage, Thousand Oaks.

Wolff, SB, Pescosolido, AT \& Druskat, VU 2002, 'Emotional intelligence as the basis of leadership emergence in self managing work teams', Leadership Quarterly, vol. 13, pp. 505-522.

Yin, RK 2009, 'Case study research: design and methods,' 4th ed., Applied Social Research Methods Series, 5, Sage, New Delhi. 